\title{
Relasi Antara Omnibus Law di Era Pandemi Covid-19 Dan Perekonomian di Indonesia
}

\author{
Mohammad Orinaldi \\ Fakultas Ekonomi dan Bisnis Islam Universitas Islam Negeri Sulthan Thaha Saifuddin Jambi \\ Correspondence email: orinaldi@uinjambi.ac.id
}

\begin{abstract}
This research aims to determine the relationship between the omnibus law in the Covid-19 pandemic era and the economy in Indonesia. This research uses a qualitative approach with literature study methods. Researchers collect related data from journals, as well as internet sources related to research keywords. Furthermore, the researcher reduced the data and presented it in the form of scientific papers. The result of this research is that the omnibus law was drafted without adequate public consultation, leaving unions, civil society groups and academics unaware of its contents and forcing them to guess even the most controversial provisions. Even now the Omnibus law has begun to be implemented in the country's economic activities. One of the most damaging aspects of the law is its provision within the environmental family, which researchers believe is designed to expand the role of the central government and significantly reduce public participation in decision-making processes on environmental issues that will have a tremendous impact on the lives of surrounding communities. So, the pros and cons are still rolling and this law is deemed incapable of solving the country's economic problems because it is not a solution idea.
\end{abstract}

Keywords: Covid-19, Omnibus law, Indonesian economy.

\section{Pendahuluan}

Omnibus law merupakan RUU komprehensif yang akan mengatur berbagai ketentuan di berbagai sektor industri menjadi satu undang-undang. Ini berupaya untuk memperkuat ekonomi dengan meningkatkan daya saing, menciptakan lapangan kerja, dan mempermudah berbisnis di Indonesia. Oktober lalu, Presiden Joko Widodo menyampaikan visinya tentang Indonesia pada tahun 2045, diterjemahkan dalam pidato bahasa Inggrisnya mengutip ucapannya, "Impian kita, pada tahun 2045, produk domestik bruto Indonesia akan mencapai US\$ 7 triliun. Indonesia akan menjadi salah satu dari lima besar ekonomi dunia dengan tingkat kemiskinan mendekati nol persen. Itulah yang harus kita tujuh".

Pemerintah menyadari bahwa untuk mewujudkan visi tersebut harus mengatasi masalah overregulasi di Indonesia. Birokrasi telah lama menghambat pertumbuhan di negara ini dan menghalangi investasi asing. Saat ini ekonomi Indonesia berada di peringkat 73 di antara 190 negara dalam daftar Bank Dunia, Presiden Joko Widodo telah menargetkan Indonesia mencapai peringkat 40. Omnibus law dirancang untuk membantu memenuhi tujuan mulia ini, sebagian dengan cara merampingkan lingkungan peraturan negara yang kompleksitas dan terkadang berlebihan. Undang-undang tersebut akan meringankan pembatasan di 11 bidang penting, termasuk undang-undang ketenagakerjaan, penanaman modal, perizinan usaha, pajak perusahaan, dan pembebasan tanah. Dengan kata lain, jika langkah-langkah ini diterapkan akan membuat Indonesia menjadi tujuan yang sangat menarik bagi bisnis dan investor asing (Greenhouse, 2020).

Uniknya, omnibus law di Indonesia dicanangkan bahkan diresmikan di era genting Negara menghadapi Covid-19. Seperti yang digemakan di media sosial bahwa Indonesia menahan penyebaran Covid-19 yang telah membuat sakit dan menewaskan ratusan atau ribuan penduduknya, memaksa banyak warganya untuk tinggal di rumah, pemerintah dan parlemennya telah memberlakukan undang-undang yang akan menyangkal hak-hak rakyat (Djalante dkk, 2020). Paling rentan terhadap berbagai efek pandemi. Omnibus law tentang penciptaan lapangan kerja, menurut klaim pemerintah dan parlemen Indonesia, adalah instrumen yang diperlukan untuk menyelamatkan negara agar tidak tenggelam lebih dalam ke jurang resesi akibat pandemi. Namun serikat pekerja dan kelompok hak asasi manusia percaya bahwa itu semua sebenarnya tidak lebih dari upaya oligarki bangsa untuk menghentikan reformasi politik di negara berpenduduk 270 juta orang, banyak dari mereka sekarang hidup di ambang kemiskinan karena Covid-19 (Lath dkk, 2020).

Kesimpulan suram seperti itu setidaknya didasari oleh tiga alasan. Pertama, undang-undang hanya akan merugikan penduduk negara, khususnya mereka yang terpinggirkan. Kedua, cara undang-undang dirancang, dibahas dan disahkan, jelas melanggar hukum internasional. Ketiga, UU tersebut secara terang-terangan dirancang untuk berpihak pada elit ekonomi-politik dan korporasi asing daripada rakyat Indonesia (Jong, 2020). Dalam analogi yang paling sederhana dan mengerikan, ini adalah izin untuk kekuasaan yang akan mengeksploitasi jutaan tenaga kerja negara dan menjarah sumber daya alamnya, terutama hutan, tempat masyarakat adat setempat menggantungkan hidupnya. Omnibus law dianggap akan dapat mengatur berbagai ketentuan di berbagai sektor industri menjadi satu undang-undang. Berupaya untuk memperkuat ekonomi dengan meningkatkan daya saing, menciptakan lapangan 
kerja, dan mempermudah berbisnis di Indonesia terutama yang porak-poranda akibat pandemi Covid-19 (Velde, 2020). Berdasarkan paparan data tersebut, peneliti tertarik memaparkan mengenai, "Relasi Antara Omnibus law di Era Pandemi Covid-19 dan Perekonomian di Indonesia."

\section{Metode}

Penelitian ini menggunakan pendekatan kualitatif dengan metode studi pustaka. Peneliti mengumpulkan data terkait dari jurnal, maupun sumber internet terkait dengan kata kunci penelitian. Selanjutnya, peneliti melakukan reduksi data dan memaparkannya dalam bentuk karya ilmiah.

\section{Hasil}

Dunia saat ini terkena dampak penyakit virus corona baru (Covid-19). Organisasi Kesehatan Dunia (WHO) mengoordinasikan upaya global untuk mengelola dampak dan menyatakan Covid-19 sebagai pandemi global pada 11 Maret 2020 (WHO, 2020). Skala dampaknya tidak dapat diterima, dan penelitian menunjukkan bahwa mungkin diperlukan lebih dari satu dekade bagi dunia untuk pulih, secara sosial dan ekonomi (United Nations, 2020) dan mungkin secara signifikan mengganggu kemajuan Agenda Pembangunan Berkelanjutan (SDGs) 2030. Pada 27 Maret, negara-negara G20 menjanjikan US\$ 5 triliun untuk melawan ekonomi global terhadap Covid-19 (G20, 2020), sementara Perserikatan Bangsa-Bangsa (PBB) meluncurkan Rencana Respons Kemanusiaan Global untuk Covid-19 (United Nations, 2020). Pandemi dimulai pada Kota Wuhan, Provinsi Hubei, Cina dan telah membawa banyak tantangan baru bagi kesehatan masyarakat di berbagai negara. Dunia telah mengalami krisis kesehatan masyarakat global dalam 20 tahun terakhir yang disebabkan oleh infeksi virus baru, seperti HIV, virus Influenza A subtipe H1N1, virus Influenza A subtipe H5N1, SARS-CoV1, MERS-CoV, dan Ebola.

Namun, hal baru epidemiologis Covid-19, yang disebabkan oleh astrain virus corona (SARS-CoV2), mengungkapkan kurangnya kesiapan kita mengingat penyebarannya yang tiba-tiba dan cepat yang membuat banyak pemerintah di seluruh dunia tidak siap. Pada 26 Maret, WHO mengeluarkan enam strategi prioritas, yang akan dilakukan oleh pemerintah untuk mengatasi pandemi. Strateginya adalah sebagai berikut: Perluas, latih dan terapkan petugas kesehatan; Menerapkan sistem untuk menemukan kasus yang diduga; Meningkatkan produksi tes dan meningkatkan ketersediaan; Mengidentifikasi fasilitas yang dapat diubah menjadi pusat kesehatan virus corona; Mengembangkan rencana untuk karantina kasus; dan Fokus ulang langkah-langkah pemerintah untuk menekan virus (WHO, 2020). Menurunkan dan menunda puncak epidemi adalah penting. Tindakan yang tidak terkontrol akan mengarah pada peningkatan cepat jumlah kasus, mencapai puncak lebih awal dan membutuhkan lebih banyak kapasitas sistem layanan kesehatan untuk merespons, sementara tindakan pengendalian yang ketat yang diterapkan lebih awal akan membantu menurunkan jumlah kasus, menunda pencapaian puncak dan perlu jauh lebih rendah. kapasitas sistem perawatan kesehatan (Word Economic Forum, 2020). Indonesia adalah negara terpadat keempat di dunia, dan dengan demikian diperkirakan akan sangat menderita dan dalam jangka waktu yang lebih lama, jika dibandingkan dengan negara-negara berpenduduk sedikit lainnya (ADB, 2020) Ketika novel coronavirus SARS-CoV2 menghantam China paling parah selama bulan Desember 2019 - Februari2020, Indonesia melaporkan tidak ada kasus penularan sama sekali. Baru pada 2 Maret 2020, Presiden Joko Widodo melaporkan pertama kali terkonfirmasi dua kasus infeksi Covid-19 di Indonesia.

Pada 2 April, negara telah mencapai 1.790 kasus yang dikonfirmasi, 113 kasus baru, dengan 170 jumlah kematian, dan1 12 jumlah pemulihan (ADB, 2020). Penelitian ini adalah salah satu publikasi akademis yang berfokus pada respons kebijakan pertama yang bertujuan untuk memberikan pelaporan singkat, analisis dan evaluasi tanggapan cepat saat ini terhadap Covid-19 di Indonesia. Untuk memungkinkan publikasi dan penyebaran informasi secara cepat, penelitian ini tidak bermaksud untuk memberikan daftar tanggapan yang lengkap, tetapi bertujuan untuk menangkap tanggapan yang dipimpin pemerintah saat ini di tengah krisis. Penelitian ini dapat dipandang sebagai evaluasi waktu nyata karena memberikan wawasan dan pelajaran bagi semua pemangku kepentingan untuk memperbaiki dan menyesuaikan opsi kebijakan yang ada terutama di tingkat nasional dari April 2020 hingga akhir krisis.

Pada 27 Januari 2020, Indonesia mengeluarkan larangan bepergian ke Provinsi Hubei, China, yang saat itu merupakan episentrum global Covid-19, sementara pada saat yang sama mengevakuasi 238 WNI dari Wuhan. Setelah laporan awal dan selanjutnya infeksi, Indonesia mulai menyadari betapa buruknya situasi tersebut, dan sejak saat itu mengeluarkan berbagai kebijakan dan tindakan untuk mengatasi Covid-19, termasuk menunjuk 100 rumah sakit umum dalam negeri sebagai Rumah Sakit Rujukan pada 3 Maret 2020. Menyikapi jumlah pasien Covid-19 yang terus meningkat, jumlah Rumah Sakit Rujukan meningkat menjadi 227 pada tanggal 18 Maret 2020. Namun, meskipun upaya tersebut dilakukan, jumlah korban terus meningkat dengan pesat. Kementerian Kesehatan Indonesia menyediakan data langsung tentang dampak Covid-19 di Indonesia (Kemenkes, 2020). Informasi terkoordinasi untuk koordinasi Covid-19 disajikan di situs web yang baru didirikan ini http://www.covid19.go.id/.

Setidaknya sejak 11 Maret 2020, publik sudah mulai menuntut secara kritis transparansi data kepada pemerintah, yang mana imbauan tersebut muncul di media berita digital (WHO, 2020) yang selama ini sudah ada 27 
kasus yang dilaporkan. Kurangnya transparansi data mungkin telah menyebabkan jumlah kasus yang sebenarnya tidak dilaporkan, atau penyebaran kemungkinan jumlah kasus sebenarnya yang terdeteksi, tetapi bukan jumlah infeksi yang sebenarnya, yang dapat tidak terdeteksi karena, misal kurangnya diagnosis yang tepat (Kristanus, 2020). Kesalahan informasi seperti itu bisa sangat menghambat tanggapan pemerintah di masa depan. Hal ini menunjukkan kemungkinan bahwa upaya tersebut belum cukup. Deteksi dini dan cepat serta diagnosis infeksi Saat ini, $R T$-PCR (reverse transcription polymerase chain reaction) adalah satu-satunya metode yang diakui untuk secara cepat dan akurat mendeteksi infeksi Covid-19 pada manusia (Statista, 2020). Pertama, enzim reverse transcriptase digunakan untuk mengubah $R N A$, yang merupakan materi genetik SARS-CoV2, dari sampel usap (swab) nasofaring, menjadi $D N A$ (langkah transkripsi terbalik). Selanjutnya, dengan menggunakan primer spesifik, bagian dari DNA hasil sintesis yang berasal dari virus diamplifikasi dengan menggunakan metode polymerase chain reaction (PCR). Hanya sampel usap (swab) yang mengandung RNA manusia dan virus yang akan menunjukkan hasil positif.

Laporan media massa di Indonesia sebelumnya, selama permulaan dan puncak epidemi di Wuhan, Cina, menunjukkan bahwa tidak ada infeksi di negara tersebut. Ini terjadi selama beberapa bulan, bahkan ketika berbagai laporan telah menunjukkan bahwa negara-negara tetangga Indonesia telah melaporkan setidaknya satu infeksi. Minimnya survei ilmiah yang cepat yang dilakukan oleh pemerintah untuk mengambil keputusan dan tindakan yang cepat telah menyebabkan banyak "ekspla-bangsa" pseudosains menyebar di Indonesia, seperti yang terlihat di media massa dan sosial, mulai dari superioritas rasial hingga alasan agama dan paranormal. Namun, laporan selanjutnya dengan kuat menunjukkan bahwa tidak ada kasus yang tidak mungkin secara ilmiah, misalnya seperti yang disarankan oleh Universitas Harvard (De Salazar, 2020) dan kemudian dikritik keras oleh Menteri Kesehatan Indonesia (United Nations, 2020). Berbagai media massa internasional dan badan asing di luar Indonesia bahkan menjadi sangat ketat bahkan sampai mempertanyakan kemampuan ilmuwan dan praktisi medis Indonesia, serta keberadaan cukup.

Pandemi Covid-19 berdampak negatif terhadap pertumbuhan ekonomi nasional di Indonesia pada triwulan II2020. Akibatnya, perekonomian Indonesia pada triwulan II-2020 mengalami kontraksi 5,32\% setelah tumbuh 2,97\% pada triwulan I-2020. Kontraksi baru-baru ini sejalan dengan pelemahan ekonomi global yang bersumber dari pandemi Covid-19 serta langkah-langkah penanggulangan berupa Pembatasan Sosial Berskala Besar (PSBB) untuk memutus rantai penularan domestik. Melalui bauran kebijakan, Bank Indonesia akan terus memperkuat sinergi dengan Pemerintah dan otoritas terkait guna memastikan efektivitas berbagai kebijakan yang ditempuh untuk membangun momentum pemulihan ekonomi. Pertumbuhan ekonomi domestik mengalami penurunan di semua komponen PDB dari sisi pengeluaran (Widjanarko, 2020). Konsumsi rumah tangga pada triwulan I-2020 mengalami kontraksi 5,51\% dibandingkan dengan positif 2,83\%. Demikian pula, investasi mencatat kontraksi $8,61 \%$, turun dari $1,70 \%$ pada periode sebelumnya. Stimulus pemerintah yang diredam sejalan dengan tren musiman juga turut menopang kontraksi konsumsi pemerintah sebesar 6,90\%, turun tajam dari 3,75\% pada triwulan I-2020. Selain itu, ekspor mengalami penurunan sebesar 11,66\%. kontraksi pada periode laporan karena menyusutnya ekonomi global dan penurunan harga komoditas internasional. Sejalan dengan permintaan domestik dan ekspor, impor mencatat kontraksi sebesar 16,96\% pada periode laporan. Seluruh sektor ekonomi mengalami kontraksi pada kuartal kedua tahun 2020, kecuali Informasi dan Komunikasi; Persediaan air; Kesehatan, Pendidikan dan Jasa Keuangan; serta Pertanian. Moderasi ekonomi terutama didorong oleh Transportasi dan Penyimpanan, Perdagangan dan Akomodasi, serta Manufaktur. Sebaliknya, sektor Informasi dan Komunikasi mencatat pertumbuhan yang lebih kuat sejalan dengan serapan media digital yang lebih besar sebagai tanggapan terhadap protokol Work From Home (WFH) dan School From Home (SFH). Selain itu, sektor pertanian didorong oleh musim panen yang sedang berlangsung (Widjanarko, 2020).

\section{Omnibus Law}

Pada bulan Februari 2020, Presiden Indonesia Joko Widodo mengajukan rancangan undang-undang (RUU) ke parlemen negara. Rancangan tersebut dikenal luas sebagai "omnibus law" dan bertujuan untuk mentransformasikan perekonomian Indonesia. RUU tersebut memiliki implikasi yang kuat bagi perusahaan multinasional yang beroperasi atau mempertimbangkan untuk berinvestasi di ekonomi terbesar di Asia Tenggara. Berupaya untuk memperkuat ekonomi dengan meningkatkan daya saing, menciptakan lapangan kerja, dan mempermudah berbisnis di Indonesia (Velde, 2020). Selain menghapus birokrasi, RUU tersebut membuat perubahan signifikan pada peraturan ketenagakerjaan Indonesia, menghapus upah minimum sektoral yang ditetapkan oleh gubernur, mengurangi pesangon hingga maksimum 19 bulan gaji (tergantung berapa lama karyawan tersebut memiliki pekerjaan itu) dari sebelumnya maksimal 32 bulan gaji. Namun, pemerintah akan memberikan dana manfaat (unemployment benefit) yang disebut tunjangan pengangguran selama enam bulan kepada korban PHK. Lembur yang diperbolehkan akan ditingkatkan menjadi maksimal 4 jam dalam sehari dan 18 jam seminggu. (Velde, 2020). Bisnis hanya akan diharuskan memberi pekerja 1 hari libur dalam seminggu, bukan 2 hari. Pembatasan outsourcing juga telah dikurangi, seperti halnya pembatasan pekerjaan dimana ekspatriat dapat bekerja. Undang-undang juga melonggarkan standar lingkungan, hanya memaksa bisnis untuk mengajukan analisis dampak lingkungan jika proyek mereka dianggap berisiko tinggi. 
Pemerintah menyadari bahwa untuk mewujudkan visi tersebut harus mengatasi masalah overregulasi di Indonesia. Berbagai birokrasi telah lama menghambat pertumbuhan di negara ini dan menghalangi investasi asing. Omnibus law dirancang untuk membantu memenuhi tujuan mulia ini, sebagian dengan merampingkan lingkungan peraturan negara yang kompleks dan terkadang berlebihan. Undang-undang tersebut akan meringankan pembatasan di 11 bidang penting, termasuk undang-undang ketenagakerjaan, penanaman modal, perizinan usaha, pajak perusahaan, dan pembebasan tanah. Dengan kata lain, jika langkah-langkah ini diterapkan akan membuat Indonesia menjadi tujuan yang jauh lebih menarik bagi bisnis dan investor asing (Jong, 2020). Omnibus law memiliki beberapa poin yang masih menjadi pro dan kontra. Terkait penyederhanaan perizinan usaha. Setiap bisnis di Indonesia sekarang memerlukan satu atau lebih izin untuk beroperasi, dan banyak di antaranya harus diperpanjang setelah jangka waktu tertentu. Tanggung jawab penerbitan izin usaha yang tersebar di banyak instansi pemerintah, baik pemerintah pusat maupun daerah. Sistem berlapis-lapis ini, yang melibatkan berbagai instansi menyulitkan investor untuk mengetahui izin usaha apa yang harus diperoleh, dimana mendapatkannya, dan bagaimana cara pengajuannya. Omnibus law memperkuat regulasi yang ada dengan menyederhanakan proses perizinan usaha di hampir semua sektor usaha, termasuk kelautan dan perikanan, energi dan sumber daya mineral, ketenagalistrikkan, infrastruktur, dan transportasi. Selain itu, banyak lisensi akan digabungkan atau dibatalkan seluruhnya.

Peran Badan Koordinasi Penanaman Modal (BKPM) akan diperkuat dan akan memainkan peran penting dalam merampingkan penerbitan semua izin usaha. Berdasarkan undang-undang yang diusulkan, investor asing dapat memperoleh izin usaha melalui sistem pengajuan tunggal (OSS) online, sehingga tidak perlu melalui banyak kementerian atau lembaga pemerintah lainnya. Omnibus law juga akan memperkenalkan sistem pendekatan berbasis risiko, membagi bisnis ke dalam kategori risiko rendah, menengah, dan tinggi (Jong, 2020). Bisnis yang dianggap berisiko rendah tidak lagi diharuskan memiliki izin usaha, hanya nomor registrasi. Bisnis berisiko menengah juga tidak diwajibkan untuk mendapatkan izin usaha, tetapi memerlukan sertifikasi standar. Bisnis berisiko tinggi tetap diwajibkan untuk mendapatkan izin usaha penuh. Melonggarkan pembatasan investasi asing. Meskipun omnibus law kurang detail implementasi tentang subjek pembatasan investasi, peraturan utama yang diusulkan berbunyi: "Semua lini bisnis terbuka untuk investasi langsung, kecuali yang ditetapkan sebagai tertutup untuk investasi atau yang merupakan kegiatan yang disediakan untuk pemerintah pusat" (Velde, 2020).

Indonesia sekarang menggunakan apa yang disebut daftar investasi negatif, yang mencakup sejumlah lini bisnis yang hanya sebagian terbuka untuk investasi asing (garis-garis ini memiliki batas kepemilikan asing). Ambil dua contoh, perusahaan yang bergerak dalam bisnis hortikultura besar terbuka untuk kepemilikan asing hingga 30 persen, dan perusahaan yang bergerak dalam bisnis penyiaran terbuka untuk kepemilikan asing hingga 20 persen. Meski belum jelas saat ini, berdasarkan omnibus law peneliti berharap lini bisnis ini dan lainnya akan sepenuhnya terbuka untuk kepemilikan asing. (garis-garis ini akan tersedia untuk 100 persen kepemilikan asing.) Jika memang demikian, undang-undang baru akan menandai liberalisasi dramatis rezim penanaman modal asing (FDI) di Indonesia. Unsur omnibus law ini harus diperjelas dengan peraturan presiden yang memuat daftar lini bisnis tertutup. Ini belum dikeluarkan. Berkaitan dengan melonggarkan hukum perburuhan, didasari Indonesia memiliki undang-undang ketenagakerjaan yang relatif ketat. Misalnya, undang-undang memberikan kompensasi pesangon wajib yang banyak, sejauh ini paling dermawan di wilayah APAC dan menghalangi banyak investor asing. Omnibus law bertujuan untuk membuat undang-undang ketenagakerjaan lebih fleksibel dan ramah pasar, serta membuatnya lebih sejalan dengan negara lain di kawasan. Harus dikatakan bahwa ini adalah topik sensitif di Indonesia yang telah menuai banyak tentangan dari serikat pekerja dan pihak lain. Meskipun hal ini tidak boleh diabaikan, beberapa penolakan akan terjadi ketika pemerintah berupaya melonggarkan perlindungan pekerja. Omnibus law juga mengatur tentang pajak perusahaan. Sebagian besar dari omnibus law yang diusulkan mencakup perpajakan perusahaan. Saat ini, ada banyak undang-undang perpajakan yang berbeda di negara ini. Pada dasarnya, UU tersebut memberikan penyatuan kerangka peraturan perpajakan Indonesia yang tersebar. Ini bertujuan untuk meminimalkan peraturan yang tumpang tindih dan memberikan banyak insentif pajak perusahaan, termasuk penyesuaian tarif berikut.

Pada tarif pajak penghasilan badan, UU ini secara bertahap akan menurunkan tarif pajak penghasilan badan dari $25 \%$ menjadi $20 \%$ untuk periode 2021 sampai 2023. Selanjutnya, perusahaan publik yang memenuhi syarat yang memperdagangkan setidaknya $40 \%$ sahamnya di bursa efek Indonesia dapat mengajukan permohonan tambahan. Pengurangan tarif 3\%. Penurunan ini akan membuat Indonesia semakin kompetitif dengan negara tetangga. Tarif pajak dividen pada UU ini akan menyediakan pembayaran dividen bebas pajak penghasilan, selama jumlah penuh diinvestasikan kembali di Indonesia. Tarif pajak bunga di Indonesia saat ini sebesar 20\% relatif tinggi dibandingkan dengan negara APAC lainnya. Omnibus law yang diusulkan akan memberikan pengurangan tarif pajak penghasilan yang berasal dari pembayaran bunga. Pengurangan pastinya belum ditentukan. Pembahasan RUU omnibus saat ini ditunda karena pandemi dan diperkirakan bisa diambil dalam beberapa bulan (Jong, 2020). Terlepas dari penundaan yang tidak dapat dihindari ini, usulan omnibus law dengan jelas menunjukkan bahwa pemerintah Indonesia berkomitmen untuk meminimalkan birokrasi di hampir setiap bidang bisnis untuk menarik investor asing. Para 
investor tersebut harus mengingat bahwa omnibus law akan dibahas di parlemen dan mungkin ada perubahan pada draf tersebut sebelum menjadi undang-undang.

\section{Relasi Omnibus law dan Dampaknya pada Perekonomian Indonesia}

Sistem ekonomi di seluruh dunia benar-benar terhenti karena arus perdagangan dan pariwisata telah menguap karena krisis Covid-19. Pada bulan Juni, Dana Moneter Internasional (IMF) memperkirakan bahwa ekonomi global akan menyusut sebesar 4,9\% pada tahun 2020, memperingatkan kondisi yang sangat keras untuk rumah tangga berpenghasilan rendah. Indonesia telah memangkas prospek pertumbuhan PDB 2020 menjadi 2,3\%, dari 5,3\%, pada bulan April (Djalante dkk, 2020). Hal itu menjadi alasan pemerintah "cepat-cepat" mengesahkan RUU omnibus law Cipta Kerja sekalipun sudah menimbulkan pertentangan sebelumnya. Undang-undang omnibus law ini dibuat tanpa konsultasi publik yang memadai, membuat serikat pekerja, kelompok masyarakat sipil, dan akademisi tidak mengetahui isinya dan memaksa mereka untuk menebak-nebak bahkan ketentuan yang paling kontroversial. Dalam contoh mencolok dari pengkhianatan kepercayaan publik oleh pejabat terpilih, parlemen Indonesia menyelesaikan RUU tersebut pada akhir pekan dan mengesahkannya menjadi undang-undang pada hari 5 Oktober 2020, tak lama sebelum serikat pekerja dapat mengatur demonstrasi. Bahkan sekarang Omnibus law sudah mulai diimplementasikan dalam kegiatan perekonomian Negara.

Pemerintah mengaku telah melibatkan 14 serikat pekerja sebagai bagian dari Tim Koordinasi Pembahasan dan Konsultasi Publik RUU omnibus law Cipta Kerja. Namun, serikat pekerja membantah klaim tersebut, dengan mengatakan bahwa mereka tidak terlibat pada awal RUU tersebut. Hal itu tidak memenuhi Pasal 25 Kovenan Internasional tentang Hak Sipil dan Politik (ICCPR), yang diratifikasi oleh Indonesia pada tahun 2005, yang memberikan hak kepada masyarakat untuk "mengambil bagian dalam pelaksanaan urusan publik, secara langsung atau melalui perwakilan yang dipilih secara bebas". Gelombang protes oleh mahasiswa dan kelompok buruh terhadap hukum telah terjadi di seluruh negeri, beberapa di antaranya disambut dengan kekerasan berlebihan oleh polisi (Hermawan, 2020). Pihak berwenang setempat sepenuhnya menyadari bagaimana reaksi masyarakat terhadap pengesahan undang-undang tersebut, dengan Kapolri Jenderal Idham Azis (Hermawan, 2020), menginstruksikan anak buahnya untuk melakukan pengawasan online terhadap aktivis dan melawan narasi online yang melanggar hukum. Ada risiko bahwa bahkan sebelum undang-undang berlaku, hal itu mungkin telah memicu gelombang pelanggaran hak asasi manusia. Minimnya informasi terkait isi RUU menjadi salah satu penyebab kontroversialnya. Pemerintah tampaknya sengaja membuat kebingungan di kalangan publik di saat dunia maya negara itu dipenuhi dengan berita palsu dan informasi yang salah. Dua hari setelah pengesahan undang-undang tersebut, pemerintah dan parlemen belum secara resmi merilis versi final undang-undang tersebut, sehingga publik mempertanyakan keabsahan dokumen yang mereka baca. Beberapa anggota parlemen bahkan dengan anehnya mengaku belum membaca undang-undang tersebut (BBC, 2020).

Fakta bahwa parlemen dan pemerintah Indonesia memutuskan untuk melanjutkan pembahasan undangundang selama pandemi memaksa orang untuk memilih antara membela hak-hak mereka atau tertular penyakit mematikan yakni Covid-19 yang harus diselesaikan dan menjadi masalah nasional. Namun, ketentuannya memiliki konsekuensi hak asasi manusia yang lebih luas lagi. Berdasarkan tinjauan Hermawan (2020) terhadap rancangan undang-undang terbaru yang beredar di kalangan kelompok masyarakat sipil, undang-undang tersebut melanggar prinsip non-mundur dan realisasi progresif yang diatur dalam Kovenan Internasional tentang Hak Ekonomi, Sosial dan Budaya (ICESCR) yang diratifikasi Indonesia pada tahun 2005. Singkatnya, undang-undang memberikan perlindungan yang lebih rendah terhadap hak-hak ekonomi, sosial dan budaya dibandingkan dengan undang-undang sebelumnya yang jauh dari sempurna (Hermawan, 2020). Pertimbangkan kelompok tenaga kerja dan lingkungan dari omnibus law. Pasal 59 undang-undang tersebut misalnya, menghapuskan jangka waktu maksimum perjanjian kerja sementara, yang praktis merampas jaminan kerja dan tunjangan kerja penuh bagi jutaan rakyat Indonesia. Pasal 77 dan 78 membebaskan pekerja di sektor tertentu dari jam kerja yang manusiawi dan kompensasi lembur, sedangkan Pasal 88C menghapus komponen biaya hidup dasar, atau KHL, dalam rumusan upah minimum bagi pekerja. Ketentuanketentuan ini akan mengingkari hak rakyat atas kondisi kerja yang adil dan menguntungkan. Wakil Ketua Federasi Serikat Pekerja Indonesia (KSBI) Jumisih (Hermawan, 2020) mengatakan pada konferensi pers yang diadakan oleh Amnesty International Indonesia bahwa undang-undang ketenagakerjaan sebelumnya cukup buruk bagi pekerja, omnibus law baru tentang penciptaan lapangan kerja akan memperburuknya.

Salah satu aspek paling merusak dari undang-undang tersebut adalah ketetapannya dalam rumpun lingkungan, yang peneliti yakini dirancang untuk memperluas peran pemerintah pusat dan secara signifikan mengurangi partisipasi masyarakat dalam proses pengambilan keputusan tentang masalah lingkungan yang akan berdampak luar biasa bagi kehidupan. masyarakat sekitar. Kebijakan ini secara praktis menghilangkan perlindungan hukum bagi masyarakat yang terpinggirkan dan mereka yang membela mereka. Pasal 29, 30, dan 31 undang-undang tersebut, misalnya, mempertahankan persyaratan dokumen analisis mengenai dampak lingkungan (AMDAL) bagi perusahaan, tetapi menghapuskan komite independen yang terdiri dari pakar lingkungan, perwakilan publik, dan LSM yang bertugas 
meninjau dokumen AMDAL. Meskipun undang-undang menyatakan bahwa penilaian AMDAL melibatkan konsultasi dengan masyarakat yang terkena dampak, tidak jelas apakah konsultasi tersebut akan dipertimbangkan untuk penerbitan dokumen AMDAL itu sendiri, terutama karena komite peninjau akan dihapuskan. Ini berarti pihak berwenang dapat memutuskan masalah lingkungan yang serius dengan pengawasan minimum, jika tidak nol, dari orang-orang yang akan menderita akibat dampak negatifnya. Selanjutnya, Pasal 50 (2), Pasal 12A dan Pasal 17A UU tersebut melarang peternakan sapi di semua kawasan kehutanan dan segala jenis kegiatan komersial di hutan adat yang tidak terdaftar meskipun pada kenyataannya banyak hutan adat yang saat ini tidak terdaftar. Kebijakan-kebijakan ini jelas melanggar norma-norma internasional, termasuk ICESCR dan Deklarasi PBB tentang Hak-Hak Masyarakat Adat yang memberikan masyarakat lokal untuk dilibatkan dalam pembuatan kebijakan yang mempengaruhi kehidupan mereka, dan juga hak untuk memiliki dan menggunakan tanah, air dan sumber daya lainnya. Undang-undang tersebut bertentangan dengan rekomendasi Komite ICESCR PBB untuk memastikan penghormatan atas persetujuan yang bebas, didahulukan dan diinformasikan pada keputusan yang mempengaruhi masyarakat adat dan sumber daya mereka.

Tahun ini saja, Amnesty International mencatat penangkapan, penyerangan dan intimidasi terhadap sedikitnya 61 pembela HAM, termasuk tokoh masyarakat adat, karena membela hak mereka dalam konflik dengan korporasi dan lembaga negara. Peristiwa terakhir terjadi di Langkat, Sumatera Utara, di mana masyarakat adat Penunggu bentrok dengan aparat keamanan, termasuk anggota TNI, saat mempertahankan tanah ulayatnya dari perusahaan perkebunan milik negara PT Perkebunan Nusantara II (PTPN II). Dengan omnibus law meletakkan karpet merah bagi perusahaan untuk mengekstraksi sumber daya alam negara dengan hambatan minimum, jika tidak nol, peneliti percaya pelanggaran hak asasi manusia terhadap masyarakat lokal hanya akan meningkat di tahun-tahun mendatang jika undang-undang baru tetap utuh (Velde, 2020). Mengingat keputusan politik Presiden Joko Widodo dalam beberapa tahun terakhir, mulai dari melumpuhkan Komisi Pemberantasan Korupsi (KPK) hingga mengangkat orang-orang yang memiliki catatan hak asasi manusia berpetak-petak ke kabinetnya, penggambaran itu tidak bisa lepas dari kebenaran. Bagi banyak orang Indonesia, presiden jelas berada di sisi sejarah yang salah. Krisis hak asasi manusia sedang di depan mata untuk negara yang sudah dilanda pandemi (Jong, 2020). Kontra masih terus bergulir sampai saat ini.

\section{Simpulan}

Sistem ekonomi di seluruh dunia benar-benar terhenti karena arus perdagangan dan pariwisata telah menguap karena krisis Covid-19, termasuk di Indonesia. Hal itu menjadi alasan pemerintah "cepat-cepat" mengesahkan RUU Cipta Kerja omnibus law sekalipun sudah menimbulkan pertentangan sebelumnya. Undang-undang omnibus law ini dibuat tanpa konsultasi publik yang memadai, membuat serikat pekerja, kelompok masyarakat sipil, dan akademisi tidak mengetahui isinya dan memaksa mereka untuk menebak-nebak bahkan ketentuan yang paling kontroversial. Dalam contoh mencolok dari pengkhianatan kepercayaan publik oleh pejabat terpilih, parlemen Indonesia menyelesaikan RUU tersebut pada akhir pekan dan mengesahkannya menjadi undang-undang pada hari 5 Oktober 2020, tak lama sebelum serikat pekerja dapat mengatur demonstrasi. Bahkan sekarang Omnibus law sudah mulai diimplementasikan dalam kegiatan perekonomian Negara. Salah satu aspek paling merusak dari undang-undang tersebut adalah ketetapannya dalam rumpun lingkungan, yang peneliti yakini dirancang untuk memperluas peran pemerintah pusat dan secara signifikan mengurangi partisipasi masyarakat dalam proses pengambilan keputusan tentang masalah lingkungan yang akan berdampak luar biasa bagi kehidupan. masyarakat sekitar. Kebijakan ini secara praktis menghilangkan perlindungan hukum bagi masyarakat yang terpinggirkan dan mereka yang membela mereka. Pasal 29, 30, dan 31 undang-undang tersebut, misalnya, mempertahankan persyaratan dokumen analisis mengenai dampak lingkungan (AMDAL) bagi perusahaan, tetapi menghapuskan komite independen yang terdiri dari pakar lingkungan, perwakilan publik, dan LSM yang bertugas meninjau dokumen AMDAL. Selanjutnya, Pasal 50 (2), Pasal 12A dan Pasal 17A UU tersebut melarang peternakan sapi di semua kawasan kehutanan dan segala jenis kegiatan komersial di hutan adat yang tidak terdaftar meskipun pada kenyataannya banyak hutan adat yang saat ini tidak terdaftar. Dengan omnibus law meletakkan karpet merah bagi perusahaan untuk mengekstraksi sumber daya alam negara dengan hambatan minimum, jika tidak nol, peneliti percaya pelanggaran hak asasi manusia terhadap masyarakat lokal hanya akan meningkat di tahun-tahun mendatang jika undang-undang baru tetap utuh.

\section{Daftar Pustaka}

ADB. 2020. ADB Approves 3 Million Dollar Grant to Support Indonesia's Fight Againts Covid-19.

BBC. 2020. Indonesia: Thousand Protest Against Omnibus law on Jobs. Diunduh pada 12 Oktober 2020 dari https://www.bbc.com/news/world-asia-54460090

De Salazar PM, Miehus R, Taylor, A., Bucke, C., Litsitch. 2020. Using Predicted Imports of Covid-19. https://doi.org/10.1101/2020.02.04.20020495

Djalante, Riyanti., Jonaan Lassa., Davin Setiamarga., Aruminingsih Sudjatma et al. 2020. Review and Analysis of Current Responses to Covid-19 in Indonesia. ELSEVIER Progress in Disaster Scrience 6. 
G20. 2020. Extraordinary G20 Leaders Summit Statement.

Greenhourse. 2020. What Foreighn Investors Need to Know About Indonesia's Proposed Omnibus Law. Diunduh pada 13 Oktober 2020 dari https://greenhouse.co/blog/omnibus-law-indonesia/

Herwanan, Ary \& Usman Hamid. 2020. Indonesia's Omnibus law is a Bust for Human Right. Diunduh pada 12 Oktober 2020 dari https://www.newmandala.org/indonesias-omnibus-law-is-a-bust-for-human-rights/

Jong, Hans Nicholas. 2020. Indonesia Bill Weakening Environtmental Guards to Pass in October. Diunduh pada 10 Oktober 2020 dari https://news.mongabay.com/2020/08/indonesia-omnibus-deregulation-bill-pass-october/ .

Kemenkes. 2020. Data Penyebaran Covid-19 di Indonesia. Kementerian Kesehatan Republik Indonesia.

Lath, Vivek., Tracy Lee., Khoon Tee Tan., \& Phillia Wibowo. 2020. Despite the Social and Economic Uncertainly and Advance Its Economy and Prepare for Strong Postcrisis Emergence. Diunduh pada 10 Oktober 2020 dari https://www.mckinsey.com/featured-insights/asia-pacific/with-effort-indonesia-can-emerge-from-the-covid19-crisis-stronger

Kristanus, Arnoldus. 2020. Slow Spending of Covid-19 Stimulus Condemn Indonesia to Worst Contraction in Two Decades. Diunduh pada 12 Oktober 2020 dari https://jakartaglobe.id/business/slow-spending-of-covid19stimulus-condemns-indonesia-to-worst-contraction-in-two-decades

Statista. 2020. Coronavirus Cases 2020. Diunduh pada 12 Oktober 2020 dari https://www.statista.com/statistics/1043366/novel-coronavirus-2019ncov-cases-worldwide-by-country

United Nations. 2020. Launch of Global Humanitarian and Response Plan for Covid-19. https://www.un.org/sg/en/content/sg/press-encounter/2020-03-25/launch-of-global-humanitarian-responseplan-for-covid-19

Velde, Floris Van Der. 2020. Indonesia: What Foreign Investor Need to Know About Indonesia's Proposed Omnibus Law. Diunduh pada 13 Oktober 2020 dari https://www.mondaq.com/inward-foreign-investment/947714/whatforeign-investors-need-to-know-about-indonesia39s-proposed-omnibus-law

WHO. 2020. Critical Preparedness, Readiness, and Response Actions for Covid-19. Diunduh pada 12 Oktober 2020 dari https://www.who.int/publications-detail-redirect/critical-preparedness-readiness-and-response-actionsfor-covid-19

Widjanarko, Onny. 2020. Government Press Release. Diunduh pada 12 Oktober 2020 dari https://www.bi.go.id/en/iru/government-press-release/Pages/National-Economic-Growth-Impacted-byCOVID-19-in-Q2-2020.aspx 